\title{
ПРОБЛЕМА ФОРМУВАННЯ НАЦІОНАЛЬНОЇ ІДЕНТИЧНОСТІ ЗРОСТАЮЧОЇ ОСОБИСТОСТІ В УМОВАХ РОЗБУДОВИ НЕЗАЛЕЖНОЇ УКРАЇНИ
}

https://doi.org/10.37472/2707-305X-2021-3-2-17-6

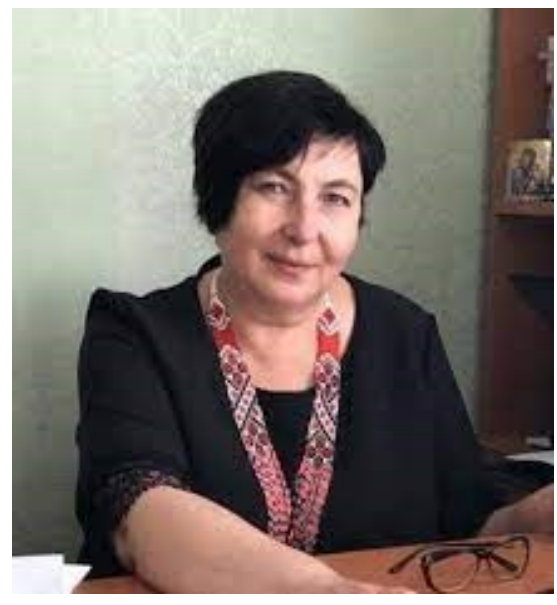

ЖУРБА

Катерина Олександрівна

доктор педагогічних наук,

головний науковий

співробітник лабораторії

морального, громадянського

та міжккльтурного виховання

Інституту проблем виховання

Національної академії

педагогічних наук України,

м. Київ, Україна

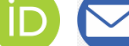

Анотачія. 26 серпня 2021 р. на базі Інституту проблем виховання Начіональної академії педагогічних наук України відбувся методологічний семінар на тему «Проблема формування національної ідентичності зростаючої особистості в умовах розбудови незалежної України» в рамках заходів Національної академії педагогічних наук України, присвячених 30-річчю Незалежності України. Співорганізаторами заходу виступили Відділення загальної педагогіки та філософії освіти НАПН України, Інститут проблем виховання НАПН України, Національний педагогічний університет імені М.П. Драгоманова, Рівненський державний гуманітарний університет. У роботі методологічного семінару взяли участь Е.Е. Барієв, І.Д. Бех, М.А. Журба, П.І. Кендзьор, В.Г. Кремень, Т.Д. Кремінь, С.О. Сисоєва., Р.Л. Сойчук, Г.Г. Філіпчук, а також вчені Інституту проблем виховання НАПН України, представники закладів вищої освіти, післядипломної освіти, загальної середньої освіти тощо. Плідна наукова дискусія учасників методологічного семінару сприяла глибокому і всебічному розумінню проблеми формування національної ідентичності в умовах незалежної України.

Ключові слова: начіональна ідентичність; начіональна культура; українська мова; національна ідея; громадянська освіта; національне самоствердження; заклади освіти; зростаюча особистість.

26 серпня 2021 року на базі Інституту проблем виховання Національної академії педагогічних наук України відбувся методологічний семінар на тему «Проблема формування національної ідентичності зростаючої особистості в умовах розбудови незалежної України» в рамках заходів Національної академії педагогічних наук України, присвячених 30-річчю Незалежності України. Співорганізаторами заходу виступили Відділення загальної педагогіки та філософії освіти НАПН України, Інститут проблем виховання НАПН України, Національний педагогічний університет імені М.П. Драгоманова, Рівненський державний гуманітарний університет.

До роботи методологічного семінару долучилися вчені Інституту проблем виховання НАПН України, представники закладів вищої освіти, післядипломної освіти, загальної середньої освіти та ін.

Модерувала захід доктор педагогічних наук, головний науковий співробітник лабораторії морального, громадянського та міжкультурного виховання Інституту проблем виховання НАПН України Катерина Олександрівна Журба.

Проблемне поле методологічного семінару включало такі питання:

- Виклики у формуванні національної ідентичності та основні фактори духовної безпеки української нації.

- Місце українського народу в сім'ї слов' янських етносів.

- Громадянське виховання учнів в контексті Нової української школи.

- Проєкти як засіб виховання громадянина-патріота у дитячих громадських організаціях. 
- Нормативно-правове забезпечення діяльності дитячих та молодіжних громадських організацій як інституцій громадянського суспільства.

- Організація національно-патріотичного виховання зростаючої особистості.

- Зарубіжний досвід формування національної ідентичності зростаючої особистості в освітніх закладах різного типу.

3 настановною промовою до учасників методологічного семінару звернувся президент НАПН України, доктор філософських наук, професор, дійсний член НАН України і НАПН України Василь Григорович Кремень, який чітко окреслив роль національної ідентичності в розвитку особистості і держави в сучасному глобалізованому світі, визначив напрями і виклики формування національної ідентичності зростаючої особистості в сучасних умовах, значення сучасної освіти у їі формуванні. В.Г. Кремень дав вичерпну відповідь щодо ідентичності українців і росіян у контексті українського державотворення.

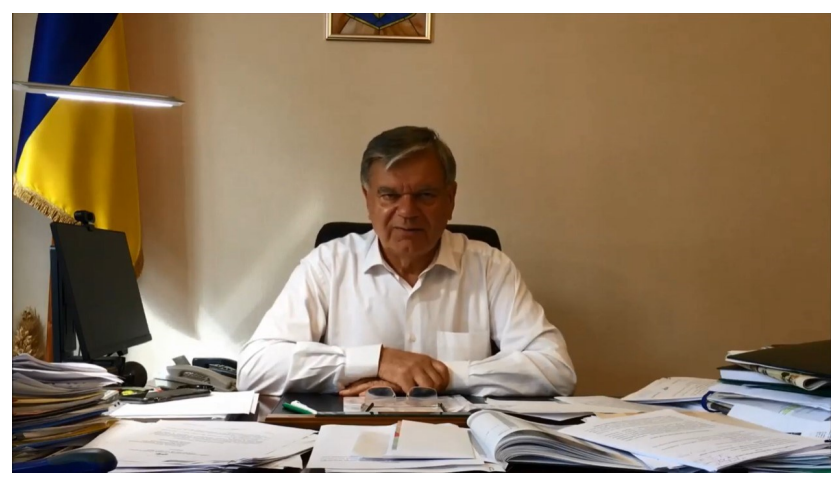

3 вітальним словом до присутніх звернулася академік-секретар Відділення загальної педагогіки та філософії освіти НАПН України, доктор педагогічних наук, професор, дійсний член НАПН України Світлана Олександрівна Сисоєва, яка підкреслила значущість проблеми, порушеної методологічним семінаром, зазначила комплексний підхід до обговорення питань виховання патріотизму, формування національної ідентичності та врахування зарубіжного досвіду їх вирішення.

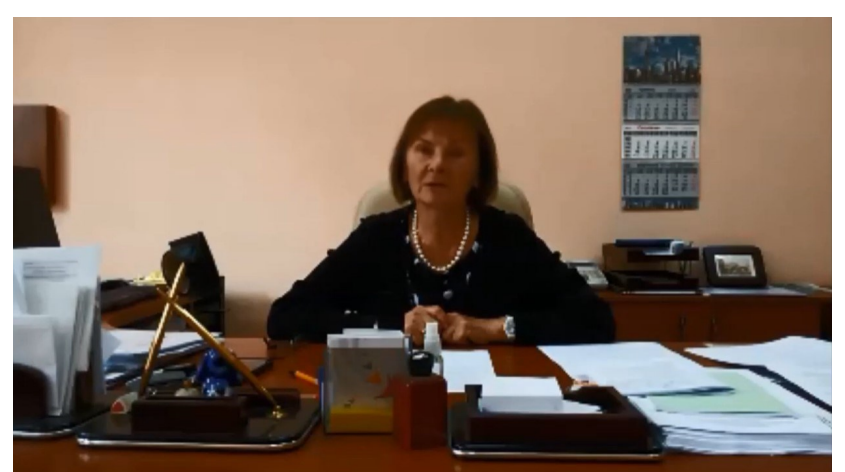

3 доповіддю «Експозиційний простір «українська мова» у закладах освіти: від ідеї до втілень» виступив Уповноважений із захисту української мови Тарас Дмитрович Кремінь, який наголосив на тому, що в Україні мають бути розроблені та затверджені регіональні програми розвитку і функціонування української мови як державної. Такі цільові програми розвитку української мови потрібно затвердити в кожній області. Окрім того, Уповноважений зазначив про необхідність створення при закладах освіти Музею української мови, який інформуватиме про історію розвитку, заборон та відродження державної мови. Концепцію музею буде розроблено спільно з Національною академією педагогічних наук України.

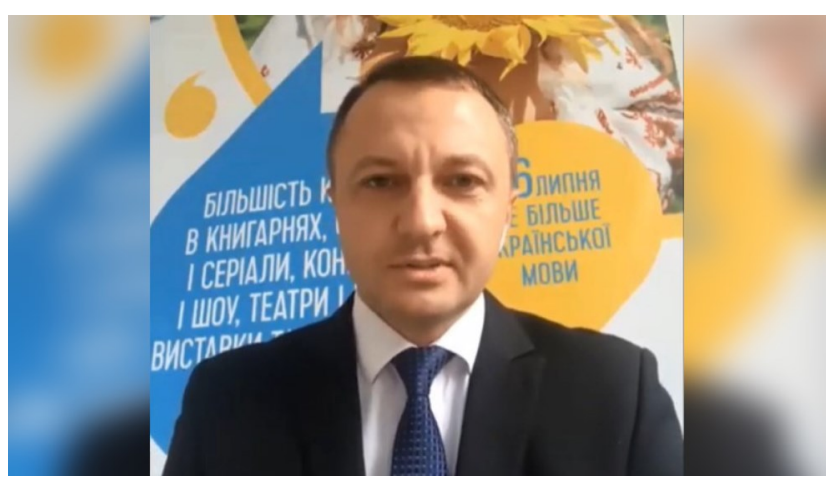

Виступ члена Меджлісу кримськотатарського народу «Питання корінних народів України у контексті формування національної ідентичності» Ескендера Енверовича Барієва стосувався проблеми національної ідентичності корінних народів України (караїмів, кримських татар, кримчаків), які стали жертвами геноциду та історичної несправедливості. Зазначено необхідність забезпечення їх прав і свобод як невід'ємного права, гарантованого Конституцією України та міжнародними документами.

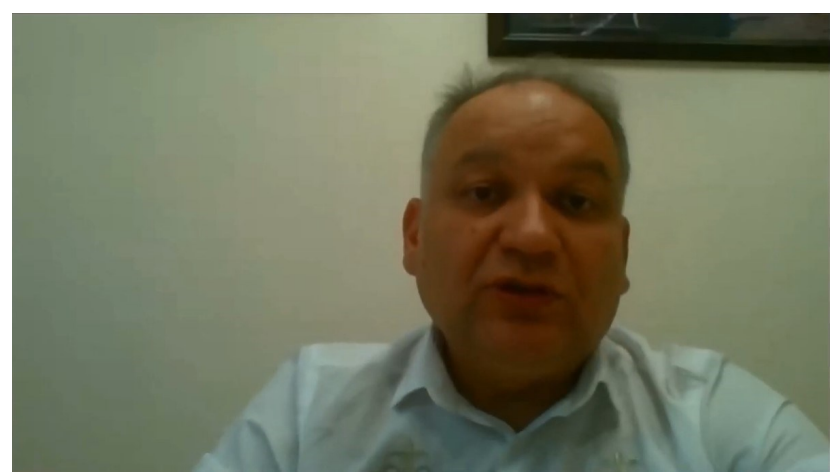

3 ключовою доповіддю «Проблема формування національної ідентичності зростаючої особистості в умовах розбудови незалежної України» виступив директор Інституту проблем виховання 


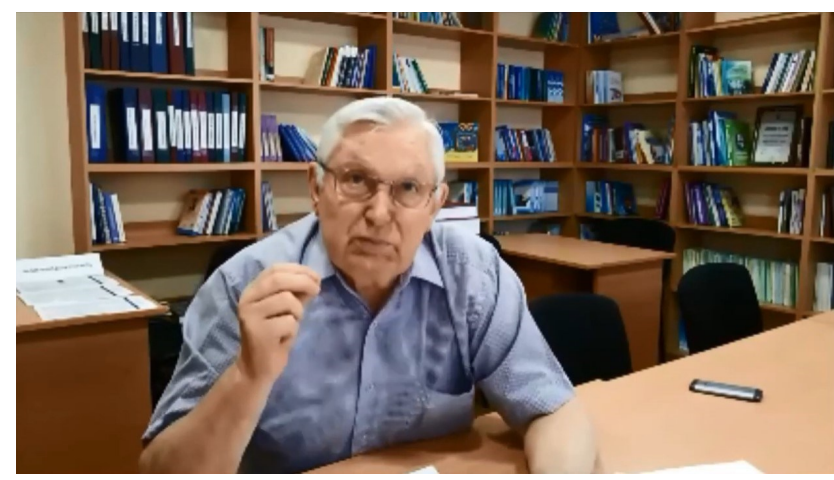

НАПН України, доктор психологічних наук, професор, дійсний член НАПН України Іван Дмитрович Бех. Вчений наголошував на тому, що національна спорідненість $€$ особливим духовним станом, коли особистість існує в малому і великому національному роді, а рід - у ній.

І.Д. Бех підкреслив, що бути національно орієнтованим невігласом - це нині злочин проти людяності. Кожна особистість має свідомо віднайти своє місце у цьому національному процесі згідно зі своїми здібностями й устремліннями, а не бути людиною натовпу, що нерозсудливо й емоційно реагує на малу чи велику подію, заражаючись загальним безумним захопленням. Представлена ним стратегія виховання дітей і молоді охоплює різноманітні чинники, виклики та умови виховання національної спорідненості зростаючої особистості в сучасних умовах.

У виступі академіка НАПН України, доктора педагогічних наук, професора Георгія Георгійовича Філіпчука «Становлення української ідентичності в сучасному світі» розкриваються засади формування національної ідентичності у зростаючої особистості (українська національна культура, українська мова, національна історична пам'ять, національна традиція і віра). У виступі Г.Г. Філіпчук приділив увагу і помилкам, які мали драматичні наслідки та стали передумовами окупації Криму та Сходу України, а також підкреслив пріоритетну роль національної ідентичності у боротьбі за українську державність. На цьому тлі місія вчителя полягає у служінні своєму народові.

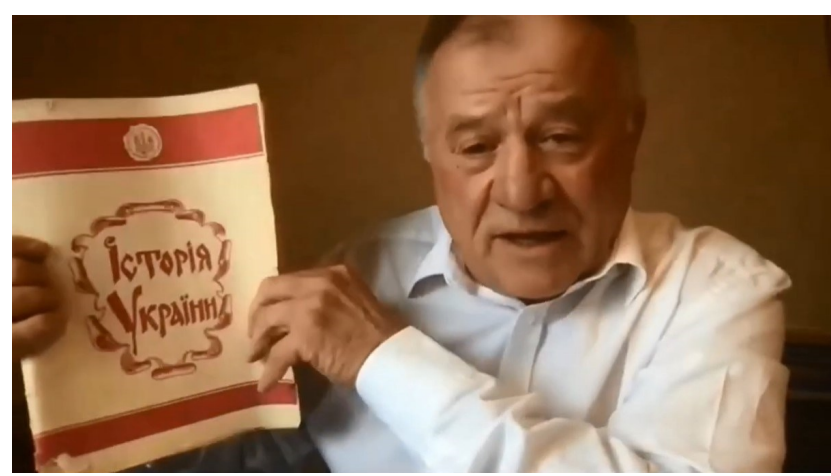

Наведені ідеї знайшли підтримку у доктора історичних наук, професора, завідувача кафедри цивілізаційної історії та археології Центральної і Східної Європи Михайла Анатолійовича Журби. У доповіді «Ідентичність у сенсі національної української ідеї» він детально проаналізував теорії української ідентичності, а також домінування російських версій (М. Погодіна, М. Карамзіна, В. Ключевського) у зарубіжній науковій думці. Учений висвітлив процеси історичних фальсифікацій, зачистки українських документів, експансії «русского міра», що обумовлює необхідність вивчати історичну правду.

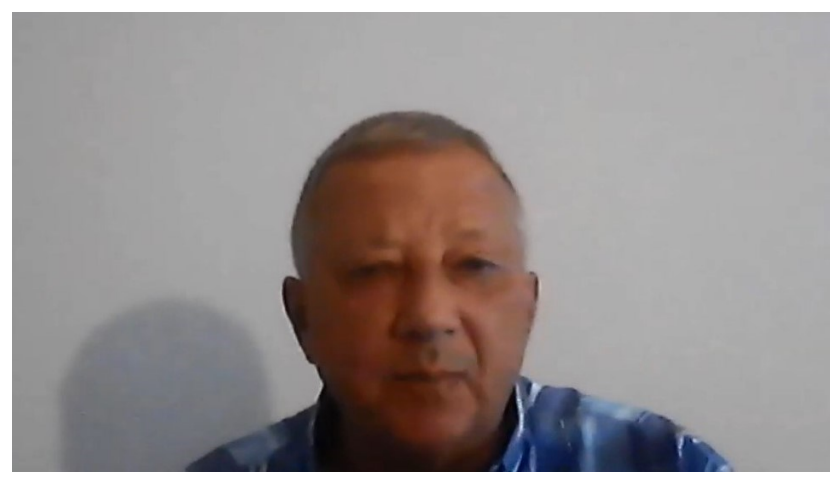

Доктор педагогічних наук, керівник освітніх проєктів Всеукраїнської асоціації викладачів історії та суспільних дисциплін «Нова доба» Петро Іванович Кендзьор у виступі «Громадянська освіта як важливий чинник консолідації українського суспільства» відзначив, що на сьогодні важливо позбутися патерналістських, пасивних очікувань та стати активними громадянами, суб'єктами, а не об'єктами у житті країни. Найбільшим викликом $\in$ не війна, корупція, пандемія COVID-19, а декларативна демократія, яка не ставить за мету конкретну діяльність. За цих умов зростає роль громадянської освіти у формуванні національної ідентичності школярів, що вчить, як не на словах, а на діях бути громадянином; як бути господарем: брати відповідальність за свої слова і дії; виявляти громадянську активність.

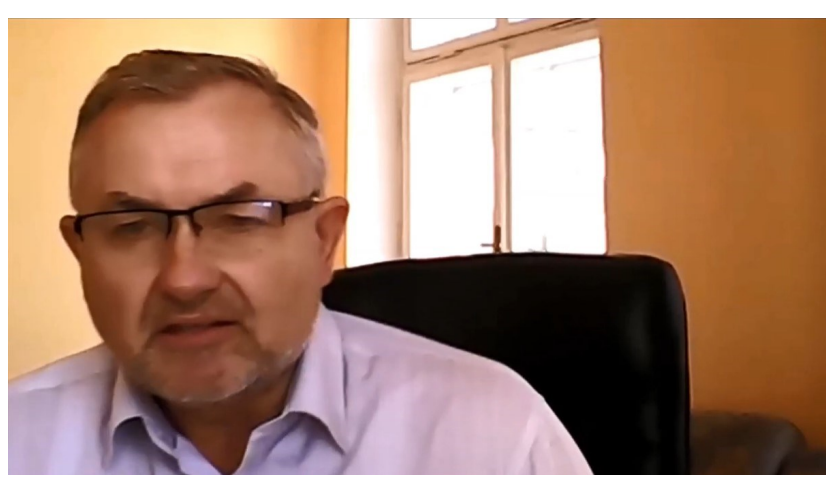


У виступі «Виховання національного самоствердження у майбутніх викладачів ЗВО як найвищої смисложиттєвої цілі особистості» доктора педагогічних наук, професора, завідувача кафедри педагогіки початкової, інклюзивної та вищої освіти Рівненського державного гуманітарного університету Руслани Леонідівни Сойчук зосереджено увагу на виборі Україною європейського шляху розвитку, творенні української нації та становленні громадянського суспільства, що активізує зростання ролі національного самоствердження як утілення в життя національної ідеї та досягнення українським народом національного успіху. Наразі процес утвердження української державності пов'язаний зі становленням громадянського суспільства й політичної нації, що потребує солідарної соціально-політичної активності громадян України.

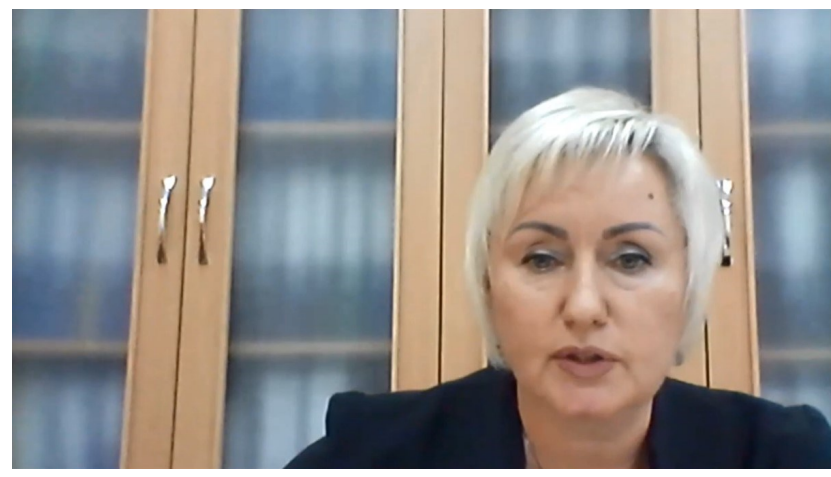

Плідна наукова дискусія учасників методологічного семінару сприяла як глибокому і всебічному розумінню проблеми формування національної ідентичності в умовах незалежної України, так і консолідації зусиль державних установ, НАПН України, закладів освіти, громадських організацій щодо створення ефективних умов формування національної ідентичності у дітей та молоді. Учасники конференції одностайні в тому, що ії матеріали стануть потужним ідеологічним підґрунтям для організації української освіти.

\section{СПИСОК ВИКОРИСТАНИХ ДЖЕРЕЛ}

Бех, І.Д., Докукіна, О.М., Федоренко, С.В., Шкільна, І.М., \& Журба, К.О. (2019). Формування в учнів основної школи національно-культурної ідентичності в контексті сучасних полікультурних впливів : посібник. Київ. https://lib.iitta.gov.ua/718616/

Горошкіна, О.М. (2021). Експозиційний простір «Українська мова» у закладах загальної середньої освіти. Вісник Національної академії педагогічних наук України, 3(1). https://doi.org/10.37472/2707305X-2021-3-1-2-9

Журба, К.О., Бех, І.Д., Докукіна, О.М., Федоренко, С.В., \& Шкільна, І.М. (2019). Національно-культурна ідентичність у становленні підлітка : монографія. Київ. https://lib.iitta.gov.ua/718615/

Журба, К.О., Бех, І.Д., Докукіна, О.М., Федоренко, С.В., \& Шкільна, І.М. (2019). Національно-культурна ідентичність підлітка: методика виховання : методичні рекомендації. Київ. https:// lib.iitta.gov.ua/718617/

Журба, М.А. (2002). Етноначіональні та міжнародні аспекти діяльності громадських об'єднань українського села (20-30 рр. XX cm.) : монографія. Київ: Науковий світ.

Інститут проблем виховання НАПН України. (2021, 28 серпня). Методологічний семінар «Проблема формування національної ідентичності зростаючої особистості в умовах розбудови Незалежної України» [Відео]. YouTube. https://youtu.be/ CD08uNxinsl

Кремень, В., \& Ткаченко, В. (2013). Україна: ідентичність у добу глобалізації (начерки метадисциплінарного дослідження). Київ: Товариство «Знання» України. https://core.ac.uk/download/pdf/158553973.pdf

Філіпчук, Г.Г. (2016). Національна ідентичність: культурно-освітній вимір : монографія. Чернівці: Друк Арт.

\title{
THE PROBLEM OF FORMING THE NATIONAL IDENTITY OF A GROWING PERSONALITY IN THE DEVELOPMENT OF INDEPENDENT UKRAINE
}

\author{
Kateryna Zhurba \\ DSc in Pedagogy, Chief Research Fellow of the Laboratory for Moral, Civic and Intercultural Education, \\ Institute of Problem on Education of the National Academy of Educational Sciences of Ukraine, Kyiv, Ukraine
}

Abstract. On August 26, 2021, on the basis of the Institute of Problems on Education of the National Academy of Educational Sciences of Ukraine the methodological seminar "The problem of forming the national identity of a growing personality in the development of independent Ukraine" was held within the NAES of Ukraine activities dedicated to the 30th anniversary of Ukraine's Independence. The event was co-organized by the Department of General Pedagogy and Philosophy of Education of NAES of Ukraine, Institute of Problems on Education of the NAES of Ukraine, Drahomanov National Pedagogical University, Rivne State University of the Humanities. E. Bariev, I. Bekh, K. Zhurba, P. Kendzor, V. Kremen, T. Kremin, S. Sysoieva, R. Soichuk, G. Filipchuk, as well as researchers of the Institute of Problems on Education of NAES of Ukraine, representatives of higher education, in-service teacher training, general secondary education institutions, etc. took part in the methodological seminar. The active and constructive debate between the seminar's participants contributed to a deep and comprehensive understanding the problem of forming the national identity in independent Ukraine.

Keywords: national identity; national culture; Ukrainian language; national idea; civic education; national selfassertion; education institutions; growing personality.

Дата публікації: 27 вересня 2021 р. 